\title{
A capoeira é só um esporte?
}

\section{Um estudo de caso sobre possessão e exorcismo na capoeira da Polônia}

\author{
¿La capoeira es sólo un deporte? \\ Un estudio de caso sobre posesión y exorcismo en la capoeira de Polonia
}

Is capoeira just a sport?

A case study on possession and exorcism in capoeira of Poland

\author{
Ricardo César Carvalho Nascimento ${ }^{1}$
}

\begin{abstract}
Resumo
A capoeira é um tipo de luta, jogo ou dança que, nas últimas décadas, obteve visibilidade e êxito transnacional, tendo sido reconhecida pela UNESCO como patrimônio cultural imaterial da humanidade. Este artigo trata do processo de transnacionalização da capoeira a partir de um outro prisma, a possessão espiritual de praticantes não brasileiros, por parte do espírito dos mestres de capoeira e, o posterior exorcismo destes espíritos. É comum, entre os capoeiristas, relatarem-se casos de transe nas rodas de capoeira, não sendo habitual ocorrerem situações e descrições de possessão. O estudo de caso, a tratar neste artigo, tem como objetivo analisar uma situação de possessão e exorcismo que se verificou na Polônia, junto a um jovem capoeirista polaco, e compreender, de que forma este fato suscitou debates sociais em torno da prática da capoeira e das formas de representação da sociedade polaca sobre si mesma e sobre a capoeira.
\end{abstract}

Palavras-Chave: capoeira; exorcismo; transe; transnacionalização.

\section{Resumen}

La capoeira es un tipo de lucha, juego o danza, en las últimas décadas, obtuvo visibilidad y éxito transnacional, habiendo sido reconocido por la UNESCO como patrimonio cultural inmaterial de la humanidad. Este artículo trata del proceso de transnacionalización de la capoeira a partir de otro prisma, una posesión espiritual de practicantes no brasileños, por parte del espíritu de los maestros de capoeira y, posterior exorcismo de estos espíritus. Es común, entre los capoeiristas, relatarse casos de trance en las ruedas de capoeira, no siendo habituales situaciones en situaciones y descripciones de posesión. El estudio de caso, un tratado en el artículo, tiene como objetivo analizar una situación de posesión y exorcismo que se verificó en Polonia, junto a un joven polémico capoeirista, y la opinión, de qué forma este hecho suscitó debates en torno a la práctica de la capoeira $Y$ de las formas de representación de la sociedad polaca sobre sí mismo y sobre una capoeira.

Palabras claves: capoeira, exorcismo, trance, transnacionalización.

\section{Abstract}

Capoeira is a type of fight, game or dance, in the last decades, obtained visibility and transnational success, having been recognized by UNESCO as intangible cultural patrimony of humanity. This article deals with the process of transnationalization of capoeira from another prism, a spiritual possession of non - Brazilian practitioners, on the part of the masters of capoeira and later exorcism of these spirits. It is common, among

\footnotetext{
${ }^{1}$ Doutor em Antropologia, Universidade da Integração Internacional da Lusofonia Afro-brasileira - UNILAB, Ceará, Brasil; ricardonascimento@unilab.edu.br.
} 
capoeiristas, to report cases of trance in capoeira wheels, not being habitual situations in situations and descriptions of possession. The case study, a treatise in the article, aims to analyze a situation of possession and exorcism that happened in Poland, together with a controversial young capoeirista, and the opinion, in what form this fact raised debates around the practice of capoeira And of the forms of representation of the Polish society on itself and on a capoeira.

Keywords: capoeira, exorcism, trance, transnationalization.

\section{Introdução}

A possessão espiritual, assim como o transe e o exorcismo, são aspetos da vida social e cultural tão antigos quanto a própria existência humana. A ocorrência e o entendimento do que pode ser a possessão diferem de uma cultura para outra e, por vezes, é compreendida por parâmetros maniqueísta da relações entre o bem e o mal, sendo, neste último caso, necessária a intervenção de um processo de despossessão, através da retirada do espírito indesejado. A prática do exorcismo associa-se a uma dimensão da cura e é um ato de esconjurar, espantar e banir espíritos cujos efeitos da possessão, sobre o indivíduo ou grupo de indivíduos, é destruidor das faculdades físicas, mentais, psíquicas e espirituais, portanto maléfico. Embora o transe seja, muitas vezes, referido pelos capoeiristas como momento de evasão mental, nas rodas de capoeira, desconhecem-se relatos de possessão por uma entidade ou espíritos provenientes de uma relação com a prática da capoeira, tão pouco ações de exorcismo. O estudo e caso que se segue, tenta analisar, no contexto do processo de transnacionalização da capoeira na Polônia, um situação social de possessão e posterior exorcismo ocorrido junto a um praticante de capoeira na Polônia, que diz ter sido possuído pelos mestres tradicionais da capoeira baiana.

O fenômeno da transnacionalização da capoeira foi marcado por vários processos de adaptação e ajustamento como indicam diferentes autores tais como Aceti (2011), Guizardi (2011), Brito (2012), Granada (2013), Fernandes (2014) e Nascimento (2015). Entre estes processos, pode-se destacar a apropriação da capoeira por parte dos locais, não brasileiros, e a forma como ajustaram, traduziram ou ressignificaram a capoeira as suas realidades cotidianas a fim de que pudesse ser difundida em seus países. Estes ajustamentos passaram, inúmeras vezes, por traduções da "cultura da capoeira" a aproximação a aspectos da vida social local, visões de mundo, paralelismos as iconografias nativas e formas de estar que facilitaram a emersão da capoeira enquanto prática aceitável e inteligível pelo conjunto das sociedades onde a capoeira foi introduzida. No entanto, nem sempre isso foi possível com facilidade, em particular em alguns países em que a capoeira, como prática associada a cultura afrodescendente, poderia ser interpretada como um perigo a cultura hegemônica, a formas 
estabelecidas de poder e visões de mundo mais conservadoras. Perspectivada por alguns segmentos religiosos na Polônia como um elemento de fomento de anomia social, refutada por ser interpretada como uma prática associada a cultos demoníacos de origem religiosa afrobrasileira, a capoeira tornou-se objeto de debate social a partir de um artigo intitulado: $A$ capoeira é só um esporte? Escrito na revista católica polaca "O exorcista” por Dominik Palka, jovem polonês ex-praticante de capoeira.

O objetivo da análise que a seguir se procederá, pretende, compreender o processo de transnacionalização da capoeira no continente europeu, a partir de uma situação social ocorrida na Polônia em que, um dos praticantes polacos, diz ter sido possuído por mestres da capoeira e posteriormente exorcizado por exorcistas católicos. Para tal, recorreu-se a análise do discurso do artigo na revista "O exorcista", , bem como a entrevistas realizadas entre os capoeiristas da Polônia e, ao acompanhamento dos debates gerados nas redes sociais. A situação social motivada pelo artigo de Dominik Palka e, seus debates subsequentes, permitem formular várias problematizações que concernem o processo de transnacionalização da capoeira, bem como, as dinâmicas culturais, sociais e políticas das sociedades ocidentais, em particular as sociedades pós-comunistas do Leste da Europa. Quais as interpretações da capoeira geradas na sociedade polaca a partir do debate sobre o artigo da revista? Como as sociedades ocidentais, em particular na Polônia, reinterpretam e utilizam a capoeira de forma a conceituar e reforçar sistemas identitários sobre a sua própria cultura e sociedade? Como os vários segmentos da capoeira da Polônia interiorizaram o debate e engajaram os seus discursos identitários sobre a relação da capoeira com a cultura religiosa afro-brasileira? São questões que concernem este artigo e que, longe de puderam ser prontamente respondidas, permeiam o leque de questionamento do autor. A fim de tentar aproximar-se da compreensão deste fenômeno, indicamos que, no âmbito prévio deste artigo, sejam tomadas em consideração as seguintes peculiaridades:

1. A pertinência de uma situação de possessão e exorcismo num país pós-comunista, a integrar-se no sistema capitalista mundial e de maioria católica.

2. O fato deste exorcismo realizar-se por decorrência de uma possível possessão a partir de uma prática cultural afrodescendente, a capoeira, no contexto transnacional.

3. A particularidade desta situação de possessão e exorcismo ter sido relatada a partir de uma revista católica local e o posterior debate social gerado pelo relato.

\footnotetext{
2 Título em polaco: “Czy cappoeira tylko sport?”, Revista O Exorcista, 2013, número 7, Cracóvia, Polônia.
} 
Por fim, reforço que, a perspectiva deste artigo não é a de examinar, a miúde, as práticas de possessão e exorcismo, mas perceber, através delas, nuances do processo de transnacionalização da capoeira, no que toca a sua efetivação no âmbito global.

\section{Processos transnacionais da capoeira na Europa e na Polônia}

Como prática, hoje transnacional, a capoeira chega a Europa nos anos setenta com os dançarinos e músicos dos grupos folclóricos brasileiros a excursionar pelo exterior, sendo os mais conhecidos o grupo Viva Bahia e Brasil Tropical. Neste período, a capoeira aporta aos espaços territoriais europeus inserida no formato da cultura afro-baiana, acomodada a outras performances cênicas como a dança dos orixás, o maculelê, o samba de roda e outros elementos da cultura negra da Bahia. Falamos de um processo de espetacularização e folclorização da cultura popular afro-baiana, antes circunscritas a Bahia e depois alargada ao Brasil mas, neste caso, a globalizar-se por força do emergente capitalismo transnacional. Conforme depoimento dos dançarinos e integrantes destes grupos parafolclóricos, mais do que a evolução das danças, a riqueza dos figurinos, teatralizações e performances, o grande atrativo do espetáculo era o corpo negro, envolto em exotismo, desejo e sedução. Alguns desses artistas, como o Mestre Martinho Fiúza, hoje residente na Alemanha e gestor de sua própria escola de dança, deixaram-se ficar na Europa e, ao excursionarem pelas capitais europeias iniciaram as primeiras aulas de capoeira. Outros seguiram-se na mesma época, como o mestre Nestor capoeira que veio a introduzir a capoeira em escolas de teatro e dança, tornando-se os pioneiros do ensino da arte na Europa. As décadas de oitenta e noventa, foram tempos de grande expansão desta prática performática afrodescendente, onde os grupos de capoeira se instalaram, criaram as suas estruturas, realizando eventos, espetáculos e deram início a formação dos primeiros capoeiristas europeus. Sobre a proeminência da cultura negra afro-baiana, Mestre Martinho dá seu depoimento como dançarino do grupo Brasil Tropical:

Aí um empresário Europeu, ele vivia em Viena, mas pelo que sei ele era húngaro, mas antes da Segunda Guerra, os pais dele fugirem pra América e ele fugiu pró Brasil e se chamava Miecio Askanasy. Depois quando acabou a Segunda Guerra Mundial ele descobriu um novo mercado de trazer grupos pra Europa. O primeiro grupo que ele trouxe pra Europa se chamava Brasiliana, foi o primeiro grupo brasileiro na Europa. Era um grupo montado só com cariocas. Então ele acabou com o grupo Brasiliana, por que o grupo brasiliana era baseado no samba, o candomblé não era candomblé era macumba. Então ele viu o programa dos Furacões da Bahia que era totalmente diferente e contratou a gente. (Depoimento do Mestre Martinho Fiúza, junho, 2013) 
Mestre Martinho destaca a importância da capoeira no âmbito das performances dos grupos folclóricos, mas sempre enquadrada no âmbito geral das apresentações que focalizam o negro, seu corpo e cultura:

A gente apresentava uma parte do espetáculo que se chamava navio negreiro. A saída dos escravos da África para o Brasil, depois vinha o lundo, depois vinha o maculelê, depois vinha a puxada de rede, mas sempre tinha intervalos, de um cantor,

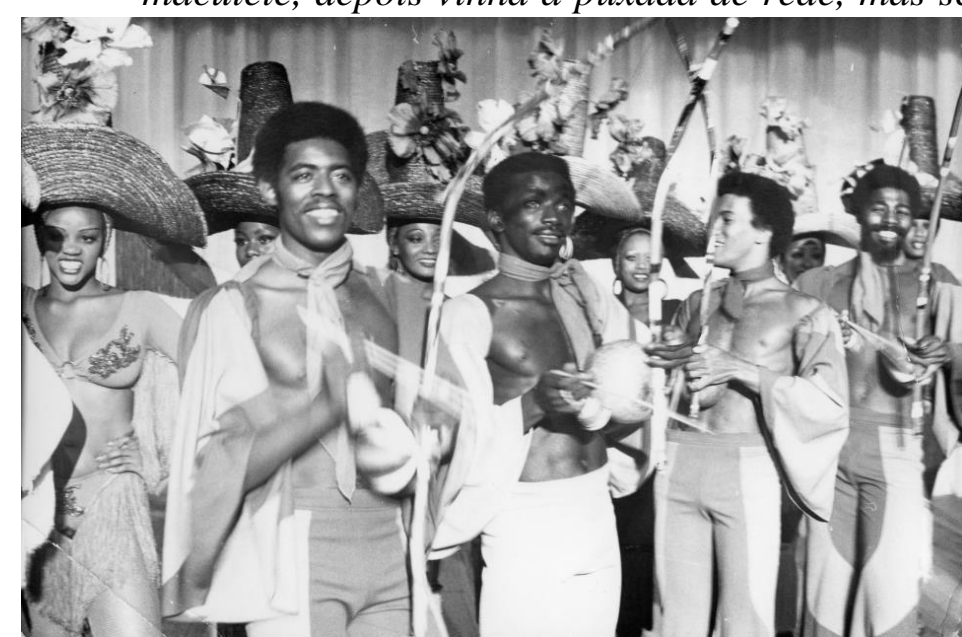

Figura 1. Apresentação do grupo Brasil Tropical nos anos 70. Arquivo fotográfico de Martinho Fiúza. um ritimista, um percussionista, que era para as pessoas mudarem a roupa, aí fechava a primeira parte com um samba de roda. Antes do samba de roda acontecia a capoeira. Então vinha um número alegre que era a capoeira com o samba de roda. Os europeus que nunca tinham visto eles ficavam assim (...) nem sei ti explicar como eles ficavam. Depois eles tentavam perguntar pra gente o que era aquilo, de onde vinha. A capoeira foi sempre muito bem aceite na Europa. Se não fosse assim ela não crescia na Europa. $O$ show no total durava duas horas e dez minutos. A gente tinha no nosso grupo muitas coisas, maracatu, samba e outras coisas. Mas quando o pessoal pedia pra gente mostrar algo a gente mostrava a capoeira. A gente queria sempre fazer publicidade de todo o Brasil, mas a capoeira era em primeiro lugar. (Depoimento do Mestre Martinho Fiúza, junho, 2013)

O crescimento da capoeira na Polônia, diferente de outros locais da Europa, fez-se a partir dos jovens polacos que, no início dos anos 90, já no final da ditadura comunista e de inserção do pais na economia global de mercado. Neste período, a capoeira já tinha sido implantada em vários locais do continente europeu, por força das migrações das primeiras gerações de capoeiristas brasileiros.

Granada (2013) apresenta um modelo trifásico que condensa o processo de internacionalização da capoeira em três diferentes etapas, sendo a primeira o da chegada dos imigrantes brasileiros capoeiristas na Europa, a segunda pela fixação destes profissionais fora do Brasil e a terceira pela apropriação da capoeira pelos não-brasileiros que hoje são os seus principais promotores. O caso da Polônia, como em todo norte e leste da Europa, contraria esse modelo. É nos anos 90 que, Adan Faba, carateca polaco, tem seu primeiro contato com a capoeira quando era emigrante na Holanda. Motivado pelo sucesso do filme "Only the 
Strong"3 o primeiro filme norte americano sobre a capoeira, Faba inicia a corajosa jornada de iniciar os primeiros praticantes polacos, ao viajar e dar aulas em várias partes do país. Será importante enfatizar que, os anos 90, na Polônia, era a década de retorno a economia de mercado, depois de um longo período ditatorial associado ao regime comunista. A entrada para o capitalista global, causou perplexidade e deslumbramento, por significar um momento de abertura e inserção a espaços mundializados, dantes pouco acessíveis. Os anos noventa foram promissores para o crescimento da capoeira na Polônia, e o trabalho iniciado por Adan Faba deu origem a inúmeros grupos, hoje ainda atuantes naquele país. Cabe salientar que, historicamente a Polônia foi sempre uma nação conservadora, cuja definição da identidade nacional esteve sempre associada a formação moral católica, reforçado pela figura do seu expoente máximo, o papa polaco João Paulo II, antigo bispo da cidade de Cracóvia.

\section{Uma perspectiva antropológica da possessão, espiritualidade e transe na capoeira}

No campo da Antropologia existem diferentes tipos de abordagens teóricas sobre o ritual, entre elas a estruturalista de Lévi- Strauss, a estrutural-funcionalista de Gregory Bateson e Victor Turner, bem como perspectivas mais fenomenológicas como as de Thomas Csordas. O que há em comum entre a compreensão destes autores, grosso modo, é o entendimento de que o ritual, tal como se apresenta no processo de exorcismo e cura, pode ser uma forma de reordenamento social e simbólico; um potenciador de mudanças atitudinais, comportamentos e afetos, bem como, um forma de interpretar o mundo.

Segundo Lewis (1997), se o ato de exorcismo pretende expulsar o espírito, em muitas culturas e tratos espirituais, é possível "domesticar o espírito" aceitando a possessão como um fato que aproxima o mundo espiritual do universo social, naturalizando a aproximação entre mundo aparentemente distintos. Este ato de dissociação mental, associado ao transe, pode ser fomentado a fim de manter uma relação com o universo do sagrado, seus segredos e magias, inúmeras vezes relacionados a cura e ao tratamento espiritual. Domar os espíritos, torna-se uma meta e significa pô-los a serviço do xamã que os incorpora e deseja utilizar seus saberes para fins espirituais e de cura. Para Lewis, a possessão pode ocorrer sem o transe e, em várias culturas, sinais de doença e enfermidades podem ser sintomas de possessão, tal como no caso relatado por Dominik Pałka. O autor explica que, nalguns situações, pode ocorre um tipo de possessão latente, e só, em reiteradas sessões, entrar em transe total. Em algumas culturas,

\footnotetext{
${ }^{3}$ Ver artigo only the strong
} 
segundo Lewis, só pode ocorrer uma possessão, se houver uma "despossessão" ou retirada do espírito do possuído. Lewis acrescenta que, nalgumas culturas xamanísticas do Ártico, os indivíduos podem possuir até três almas de forma que, a possessão, deve acarretar o afastamento temporário de uma delas. Para alguns dessas culturas relatadas por Lewis, faz-se uma clara distinção entre uma possessão voluntária e involuntária, sendo a primeira entendida como um objetivo da vocação xamanística e a segundo enquanto doença. Lewis relata que, em seus estudos sobre a possessão, a identidade dos espíritos pode ser um elemento significativo, na relação entre possuído e possuidor, sendo que a constatação de que se trata de um espírito estrangeiro, pode agravar os sintomas do possuído.

Pinto e Rijo (2014) afirmam que, no âmbito do ato de exorcismo, seu primeiro momento constitui um esforço de auto identificação do demônio possuidor, o que equivale a um tipo de subjugação a Deus e um primeiro passo para a limpeza espiritual. Estas autoras esclarecem que a possessão demoníaca pode ocorrer por duas vias: a contratual, em que o indivíduo pactua com o Diabo para a obtenção de um desejo, o que acarreta numa entrega final do seu espirito ao capeta; a segunda como imposição em que o espírito malfazejo reivindica apenas o invólucro físico do possuído e não sua alma. Segundo Pinto e Rijo (2014), o processo de expulsão do espírito, no cristianismo católico, é muito simples e, tem como base, descrições de exorcismos realizados por Cristo e descritas nos quatro evangélicos. O exorcismo reside no ato de ordem de expulsão do demônio, previamente identificado, feita em nome de Jesus, tendo o sacerdote como veículo mediador da expulsão, uma vez que quem o consuma é a força divina de Deus. Conforme estas autoras, existem dois tipos de exorcismo no cristianismo católico, o exorcismo menor e o grande exorcismo. O primeiro ocorre no rito de celebração do batismo, regra geral nos primeiros anos de vida das crianças e, quanto ao segundo, é o que ocorre por ocasião de uma possessão e só pode ser realizado por um presbítero, por consentimento de um bispo e quando explicações médicas estiverem sido descartadas.

Conforme Ligiéro (2008) as práticas culturais de origem afro-brasileira como o samba, a capoeira e as religiões afrodescendentes no Brasil possuem várias características comuns que decorrem da sua motriz africana tais como: a formação em círculo; a existência de um mestre que figura como uma autoridade, repositor de saberes e ancestralidades; uma linguagem polifônica entre luta, dança e o jogo dramático; a ocorrência eventual do transe e de trânsitos rituais e performáticos entre o sagrado e profano. Esta ambiguidade, que é recorrente nas práticas afrodescendentes, faz que com a capoeira associe-se a religiosidade de motriz 
africana e um tipo de espiritualidade do tipo New Age em que não há uma divindade a ser adorada, sendo a capoeira ela mesma motivo de exaltação e êxtase religioso.

O transe na capoeira é uma experiência relatada por muitos praticantes, em particular os mais velhos. em que, não necessariamente, há o fenômeno da possessão, mas apenas a descrição de um evasão mental tal como nos diz Decânio Filho:

"O capoeirista deixa de perceber a sí mesmo como individualidade consciente, fusionando se ao ambiente em que se desenvolve o jogo da capoeira. Passa a agir como parte integrante do quadro ambiental e procede como se conhecesse ou apercebesse simultaneamente, passado, presente e futuro (tudo que ocorreu, ocorre e ocorrerá a seguir), ajustando se natural, insensivel e instantaneamente ao processo atual." (Decânio Filho 4, 2002).

No entanto, ao avançar na descrição o Dr. Decânio, como é conhecido o já falecido aluno de Mestre Bimba, criador do segmento da capoeira conhecido por Capoeira Regional, é enfático ao aproximar "o transe capoeirando", como ele o designa, ao transe experimentado no Candomblé:

"Um processo semelhante ao transe dos orixás no candomblé, diferenciando-se pelo grau de inconsciência menor, desde que, em nosso caso, conserva-se o estado de alerta e esquiva permanente contra situações de perigo atual ou potencial e aceleram os procedimentos de autopreservação e contra-ataque." (Decânio filho 4, 2002).

Brito (2012) advoga que existe uma perspectiva invisível do jogo da capoeira em que “avatares espirituais" se apropriam dos jogadores e que, por sua vez, influenciam os jogos visíveis, portanto corporais. A existência destas narrativas pode ocorrer em praticantes que possuem uma relação com as religiões afro-brasileiras e, não é frequente na grande maioria dos capoeiristas.

É importante destacar que, os relatos de transe, considerado como estado de alteração da consciência, momento de alerta e contrição, bem como algum tipo de possessão, discreta e associada a este transe, ocorrem sempre no âmbito da roda de capoeira. A roda, nesta circunstância, funcionaria como momento ritual, semelhante as giras de Umbanda ou Xirês dos Candomblé, em que se dá o chamamento espiritual e, em que a relação com o sagrado se efetiva.

Para muitos mestres, é impossível dissociar a capoeira da sua relação com as religiões de matriz africana no Brasil. O momento da roda é um momento de contrição religiosa que requer respeito e seguimento ao preceito de regras que se assemelham a um momento de adoração espiritual. A esse respeito Mestre Moraes, respeitado impulsionador da Capoeira Angola, diz-nos o seguinte: 
"A energia da roda de capoeira está diretamente relacionada à capacidade dos tocadores os quais têm função semelhante, nas devidas proporções, aos tocadores de candomblé (alabês) que, através do ritmo e da música, conseguem fazer contato com orixás, inquices ou voduns a depender da nação -, e assim convidá-los para participarem da festa. Na roda de capoeira também é possivel essa relação dos tocadores com essa ancestralidade(espiritualidade) da capoeira, desde que esses tocadores estejam preparados para fazer essa comunicação. No caso específico da capoeira, inexiste a necessidade de iniciação, como acontece com os alabês, como alguns podem vir a acreditar, mas é indispensável o aprendizado anterior com um mestre de capoeira que tenha a condição de transmitir os segredos dessa comunicação." (Depoimento de Mestre Moraes em seu blog${ }^{4}$ )

Contudo, é frequente, nos eventos, rodas e aulas o apelo a novas espiritualidades que, se acomodam a prática da capoeira, enquanto prática representada como libertária, e servem de motivação de consumo religioso e, um adicional ao pacote habitual de prática da capoeira. Felix (2014) relata a recriação do Temazcal, ritual ameríndio xamânico de limpeza física, espiritual e mental encontrado no México e na Guatemala que se realizada no encontro Permangola, organizado anualmente pelo Mestre Cobra Mansa, no interior na Bahia, e que une a prática da permacultura e da Capoeira Angola.

\section{Exorcismo e possessão na capoeira da Polônia}

Dominik Palka é um jovem polaco que praticou capoeira durante cerca de dois ou três anos no seu país natal. Passei a conhecê-lo quando tomei conhecimento de uma revista polaca de inspiração religiosa cristã, de tiragem mensal, intitulada O Exorcista (O Egzorcysta), onde ele, na publicação número 7, de 2013, escreveu um artigo intitulado: A capoeira é só um desporto? Apesar de, neste artigo, falar da sua vivência como praticante de capoeira, não constam dados sobre o grupo do qual ele fez parte, qual o contexto, se sabia tocar, cantar, falar português, entre outros elementos inerentes à prática. Entretanto, na leitura do artigo, percebe-se que o seu grau de envolvimento com a capoeira era significativo, bem como o conhecimento dos mestres baianos fundadores da capoeira moderna, como Bimba e Pastinha. Contudo, é de suspeitar que Palka não falava português - o que não constatei na maioria dos praticantes que possuem o mesmo tempo de prática que ele na Polônia - uma vez que ele diz nunca ter percebido o que cantava usualmente nas rodas. Sabe-se também que Palka treinava outras artes marciais e era pouco religioso, principalmente no início do seu envolvimento com a capoeira. A sua aventura com as artes marciais começou aos sete anos e durante a

\footnotetext{
${ }^{4}$ http://mestremoraes-gcap.blogspot.com.br/2009/05/roda-de-capoeira-um-espaco-sagrado.html
} 
adolescência ele interessou-se por Punk rock, Hip Hop, Rap e outras tipos de "subculturas" como ele as designou. Dominik relata que sentia-se escravizado por estas subculturas que envolviam o consumo de drogas e saídas noturnas. Depois de começar a treinar capoeira durante um ano ele reiniciou-se noutras artes marciais e confessou que sentia um aumento da agressividade, decorrente da pressão inerente a estes desportos de combate. Palka diz ainda ter sentido sintomas de depressão, ansiedade, baixa autoestima e problemas físicos como dor na coluna e dor de estômago. Foi aí que ele resolveu procurar psicólogos, psiquiatras que, entre outras coisas, lhe receitaram fármacos cujos resultados foram nulos.

Durante algum tempo tentei encontrá-lo, escrevi para a revista a fim de que fosse possível obter o seu correio eletrônico ou o contato telefónico, mas não obtive resposta. Procurei na internet, especulei junto aos grupos, mas ninguém me conseguiu indicar o seu paradeiro ou sequer identificar o nome. Suspeito que trata-se de um nome fictício, criado talvez para a publicação do artigo, cujo conteúdo é polémico e poderia gerar reações indesejadas contra a sua pessoa. Confesso que, após tantas releituras do artigo, ele tornou-se uma personagem para mim, alguém saído de um filme cujas imagens só as pude criar no meu imaginário. No entanto, acabei por dar pelo seu paradeiro noutros sítios da internet, onde o tema por ele levantado se tornou viral, gerando debates calorosos sobre o tópico do artigo. Palka, no artigo, narra um episódio de possessão que decorreu da sua longa ligação à capoeira e cuja cura só pôde ser obtida pela intervenção de um experimentado padre exorcista polaco ao longo de exaustivas sessões que duraram trezentas horas. Após ter passado por especialistas da medicina tradicional e profissionais na área do foro da psicologia, foi por mero acaso que deu conta dos trabalhos de exorcismo e foi aí que viu tratado o seu problema. Os exorcistas polacos diagnosticaram que tratava-se de uma patologia grave de possessão pelos espíritos dos mestres de capoeira que o possuíam. Chamou a atenção do jovem polaco o facto de, na primeira consulta que teve com os padres exorcistas, não lhes ter referido que era praticante de capoeira, ou seja, o facto ter-lhes-ia sido revelado através da sua conexão com as forças divinas do além.

Destaco em particular o fato do número da revista em que saiu o artigo de Palka ter sido inteiramente dedicado ao Brasil, com artigos que referiam a vinda do Papa Francisco para um encontro mundial de jovens católicos no Rio de Janeiro, bem como missões de padres polacos em terras brasileiras e artigos dedicados ao tema do Candomblé e da Umbanda. No que toca a estas religiões, referiu-se principalmente o caráter demoníaco destes cultos afro-brasileiros e o facto de eles decorrerem, no Brasil, da ignorância das populações 
pobres brasileiras e do seu possível "primitivismo". No entanto, chama a atenção a descrição e o conhecimento minucioso dos rituais religiosos de matriz afro no Brasil.

A revista O Exorcista foi criada em setembro de 2012 e a sua tiragem inicial era de quinze mil exemplares, tendo duplicado a quantia no número de julho de 2013. Segundo os idealizadores da revista, os exorcistas na Polônia passaram de quatro para mais de cento e vinte em quinze anos. Para além desse aspeto, afirmam os editores que a categoria do ocultismo tornou-se um vasto mercado aberto pelo capitalismo no seu país, sendo os profissionais desta área tributáveis pelo sistema fiscal. Convém destacar que, na publicação número sete da revista, de 2013, Palka assina um segundo artigo que se chama: Dança em homenagem aos ídolos. Este artigo complementa o primeiro, uma vez que introduz um debate filosófico e cultural sobre a espiritualidade e a religiosidade e demonstra como práticas aparentemente inocentes, como a capoeira, podem esconder adorações espirituais indiretas.

Quando tomei conhecimento da revista e do número em questão, confrontei os meus interlocutores com o conteúdo dos artigos e como viam este tipo de ataque a uma arte tão bem difundida no seu país. Na maioria das vezes fui motivado a desvalorizar o conteúdo bem como a revista, tida por todos como pouco representativa das ideias da sociedade polaca, sendo sempre associada a setores extremistas da Igreja Católica. No entanto, o efeito viral do artigo foi notório, como pude constatar em inúmeros sítios da internet em que o debate se instalou. Mais ainda, a relação entre a capoeira e a religião afrodescendente nunca foi muito clara entre os praticantes e sempre gerou entraves ao crescimento da arte. Contudo, este aspeto não constituiu impedimento para que a Polônia se tornasse um dos países europeus com maior número de aderentes à modalidade.

Ouvi dos capoeiristas polacos muitos relatos de situações inusitadas das relações entre a religiosidade cristã polaca e a prática da capoeira. Uma delas foi-me contada pelo professor Francês na cidade de Cracóvia:

"Eu fui numa cidade e cheguei lá para fazer uma apresentação, e a gente queria fazer um trabalho lá, na cidade próxima onde o papa polaco nasceu, e lá na escola eles falaram, o que isso é capoeira? Você não sabe que capoeira é proibida pela Igreja? Não, eu falei, que proibida por igreja? Tem nada a ver não, isso é coisa muito boa. Ela escutou provavelmente algo que não tem nada a ver. Ela falou que a capoeira é uma seita. Em outro momento estávamos organizando um acampamento de capoeira e lá tava também um acampamento de um coral de igreja. Ele ficou chateado com a gente com a bagunça e o barulho que a gente faz, berimbau, tabaque e tudo. Ela falou pra organização que eles deixaram entrar pessoas de uma seita. A direção chamou-me e eu cheguei com documentos registados que somos um clube de esporte que estamos como uma disciplina do esporte. O cara tinha de pedir desculpas. "(Depoimento do professor Francês, novembro, 2012) 
Em conversa com os capoeiristas polacos, é frequente referirem-se a capoeira como uma prática esportiva, desprovida de qualquer ligação cultural afrodescendente. Tal como no caso acima, vivenciado por um líder de um dos grupos de capoeira local na cidade de Cracóvia, a mostra dos "documentos registrados" posiciona socialmente a capoeira enquanto "clube esportivo", uma espécie de espaço social de lazer e prática meramente física. Um outro momento importante da fala do nosso interlocutor é a ideia de "uma disciplina do esporte". A perspectiva de disciplina, rigor, método e eficácia é algo que, regra geral, aplicase as práticas esportivas de competição, tal como situam muitas vezes os jovens polacos praticantes da capoeira Regional Contemporânea. O carácter ritualístico, ambíguo, algo que, como disse Ligiéro navega entre o sagrado e profano, ai pouco se aplica.

"Aqui na nossa academia tem um cara que treina artes marciais. Um dia ele tava sozinho na sala fazendo umas bananeiras eu convidei ele pra fazer capoeira. Ele falou, capoeira, eu não vou. Ele falou que se confessa com um padre que disse pra ele que não pode treinar capoeira, porque capoeira é um Deus e o povo quando se junta, é um ritual pra chamar aquele Deus da África que se chama capoeira. Esse cara que eu conversei com ele, ele é bem informado, ele sabe muitas coisas, ele viaja muito. Eu disse pra ele eu sou instrutor de capoeira, não tem nada disso não, não tem nada a ver. A capoeira é uma coisa, a religião é coisa privada, se você quer ser católico, cristão ou até macumbeiro, é coisa sua, eu não tou nem aí. "(Depoimento do professor Francês, novembro, 2012)

Na fala do nosso entrevistado a dimensão espiritual da capoeira, no que toca a sua relação mais ampla com a cultura afro-brasileira, tem pouca importância enquanto legado e património cultural. Tal como observei, durante minha pesquisa de campo, uma parte do trabalho de aproximação e adesão dos novos praticantes faz-se na tentativa de "desmistificar" a capoeira, mostrando-se como uma prática divertida, alegre, associada ao imaginários dos trópicos, do calor e da diversão.

Nos anos noventa, no final das ditaduras comunistas e na entrada dos países do leste europeu nas economias de mercado mundiais, amplificaram-se as possibilidades de acesso aos mais diversos produtos culturais exibidos nas prateleiras globais. Práticas como a espiritualidade new age, tipos de consumo associados ao esoterismo, as medicinas alternativas, tornaram-se hábitos de consumo usual, principalmente entre uma nova classe média emergente. Associada a esse novo tipo de consumo cultural, a capoeira apresenta-se como uma possibilidade atrativa na formação identitária de uma nova Polônia, mas cosmopolita e global, porém, não menos conservadora (Marcin e Kubicki, 2012).

Na minha pesquisa entre os capoeiristas e na internet fui levado a vários sítios na web polaca que trataram do tema da capoeira e religiosidade na Polônia, todos, de alguma forma, 
relacionados com o artigo de Dominik Palka. Entre eles, dois chamaram-me a atenção: uma página web independente chamada de "Perigos espirituais" e a página web dos Jesuítas na Polônia 5 .

A primeira página da web é bastante conhecida e traz uma lista extensa de práticas que, segundo os autores, constituem um perigo ao católico polaco. A capoeira encontra-se na quarta posição numa lista constituída por dezanove "perigos espirituais". Entre os outros elementos da lista encontra-se o Aikido, a Yoga, os horóscopos, sendo ainda possível encontrar práticas terapêuticas alternativas, entre outras. Por perigos espirituais os autores compreendem como sendo: "todas as atividades humanas que, de alguma forma, mais ou menos direta, tendem a quebrar o relacionamento com Deus". O que mais chama a atenção dos textos apresentados na página é o grau de descrição das práticas enumeradas, que podem conter dados históricos, indicações da sua difusão na Europa e, em particular, na Polônia e, como conclusão, um elenco de razões que devem fazer refletir um cristão para que se afaste destas práticas. $\mathrm{O}$ artigo referente à capoeira faz menção ao Axé, como força espiritual não especificada cujo culto contém perigos. Faz ainda referência ao batismo cristão e ao batismo na capoeira, sendo o último uma forma de iniciação inocente em que o neófito filia-se à capoeira como prática demoníaca.

O segundo artigo, assinado na página web dos Jesuítas por Michael Karnawalski, é bem anterior ao artigo de Palka e data de 2010. O texto é breve e conciso, de poucos argumentos. Contudo, no seu escopo, encontrei a réplica de comentários interessantes que demonstram o efeito viral do tema. Num dos comentários datados de 2012, uma mãe ou pai, expõe a preocupação com o seu filho pequeno que praticava capoeira há um ano e que, num batizado, havia recebido a sua primeira graduação. $\mathrm{O}(\mathrm{a})$ progenitor(a) mencionado(a) refere ainda que o filho recebeu um nome de batismo, como é usual na capoeira e, ao ler na internet um artigo enviado por um amigo sobre os perigos da capoeira, ficou receoso(a) com o bem-estar físico, emocional e espiritual da criança, pretendendo saber se deveria exorcizá-la. Tal como pude constatar, surgiram muitas respostas, todas a enfatizarem o caráter demoníaco da capoeira e de adoração indireta às divindades do panteão religioso afro-brasileiro, uma delas assinada com o nome Dominik, sem referir o sobrenome.

\footnotetext{
${ }^{5}$ Perigos espirituais: http://zagrozeniaduchowe.pl/?p=549; Fórum dos jesuítas: http://www.rozmawiamy.jezuici.pl/forum/109/n/940

Tradução nossa do texto de apresentação da página web:http://zagrozeniaduchowe.pl/
} 
$\mathrm{Na}$ verdade, a diabolização da capoeira como prática associada aos negros e às suas crenças ditas primitivas não é nova. Calainho (2008) relata que na inquisição, em Portugal, os negros eram perseguidos por seus costumes, sempre associados a práticas demoníacas:

"A suposição de "amizade" que muitos tinham com o Demônio contribui bastante para um largo processo de demonização dos negros e mulatos: seus costumes, suas crenças e sua religiosidade foram incansavelmente detratados e associados ao Belzebu" (Calainho, 2008 p. 24).

Mais recente, no estudo realizado por Pereira (2007) na região do ABC paulista sobre a Capoeira Gospel - segmento cristão evangélico da capoeira - demonstra que esta tem crescido muito nos últimos anos e propõe uma retirada sistemática de tudo o que concerne à cultura negra que possa, de alguma forma, se aproximar das religiões afrodescendentes no Brasil. Nalguns casos o atabaque foi retirado, devido ao seu papel sagrado na Umbanda e no Candomblé, inclusivamente as músicas que fazem menção às divindades do panteão religioso afro-ameríndio brasileiro.

Segundo Campos e Gusmão (2008) num artigo sobre rituais de exorcismo da Igreja Universal do reino de Deus (IURD), os autores explicam que, os rituais da cura e do exorcismo, são um aspeto importante da liturgia daquele religião, constituindo uma forma de angariação de seguidores no mercado religioso. O exorcismo constitui-se uma prática corrente de iniciação e depuração do associado religioso e, é comum a existências de folhetos, cartazes e chamadas televisas que enumerem o que chamam de dez sintomas de possessão demoníaca: nervosismo, dores de cabeça constante, desmaios, ataques, desejo de suicídio, doenças que os médicos não descobrem as causas, visões de vultos, audição de vozes, vícios e depressão.

É importante enfatizar que, o exorcismo, seja no caso da IURD ou mesmo no caso do capoeirista polaco, é um ritual de passagem, reordenamento e reposicionamento simbólico do indivíduo em que, livrando-se de uma mal que o assola, apresenta-se como um novo ser social que encontra-se socialmente apto a integrar-se a uma nova forma de pertencimento, que pode ser uma instituição religiosa no caso da IURD ou, num escala mais ampla, a sociedade polonesa, no caso de Dominik.

Tal como nos processos inquisitórios da idade média em Portugal descritos por Calainho (2008), aqui também observa-se a necessidade de redimir-se, sendo o ato de submissão ao exorcismo uma declaração formal de arrependimento. No que toca os processos inquisitórios contra os negros, Calainho descreve que era possível, fazendo uso da confissão 
aparentemente voluntária, obter o alivio de algumas penas gravosas, caso o negro confessasse a sua relação com capeta, através de práticas religiosas:

"As "abjurações" eram declarações de arrependimento que variavam em função da gravidade do crime, era classificada ao arbítrio dos inquisidores segundo o posicionamento do réu diante do delito: se confessava a heresia, se insistia em negá-la, se arrenegara a fé e a igreja, se de fato se arrependera". (Calainho, 2008 p. 255).

Julgo que um dos aspetos iniciais deste tópico será enfatizar o primeiro caso de possessão na capoeira ocorrido na Polônia. Inicialmente fui tentado a pensar que tratava-se apenas de uma forma de combate à prática da capoeira, vista na Polônia como uma ameaça aos cristãos católicos. No entanto, não pude, mesmo não tendo entrevistado a pessoa em causa, desconsiderar o facto de alguém, num lugar remoto do globo, alegar ter sido possuído pelos espíritos dos mestres de capoeira. Mesmo que fosse mera invenção, acentuo o efeito viral do tema, por ter sido apresentado numa revista de grande circulação na vasta comunidade católica polaca e, mais ainda, por ter sido alvo de aceso debate entre as famílias polacas e os praticantes.

\section{Considerações finais}

Os contornos dessa possessão não ficaram claros no artigo, como ocorria, quando, onde e em que circunstâncias e tão pouco ouvi falar de outros casos. Na maioria das vezes, todo o constructo ritual da capoeira era, para os jovens polacos que entrevistei, apenas uma forma de acentuar a performance do jogo e da roda. No entanto, devo reconhecer que os cristãos polacos de alguma forma elucidaram o que de facto mais atraia os seus compatriotas à capoeira: o Axé. Por diversas vezes, o conceito foi referido nos artigos de Palka e nos demais a que tive acesso. O Axé pode ser entendido, na capoeira, como uma força que emana da reunião coletiva à volta da música, das palmas e do jogo, que conduz a um estado de bemestar físico e mental dos praticantes. Está claro que ele existe e não teria tanta importância se tantos não o tentassem diabolizar. Claro também está, para os seus contestadores, que se trata de um conceito religioso e que religa a capoeira a práticas espirituais pelas quais sentem repulsão e temor.

Aparentemente constitui uma contradição pensar que a capoeira cresce de tal forma num país com uma histórica hegemonia católica conservadora ao ponto da mesma definir, em alguns aspetos, o entendimento da identidade nacional polaca. Coincidência ou não, o crescimento da prática do exorcismo na Polônia acompanha o crescimento da capoeira bem como da espiritualidade New Age, da Yoga e outras práticas consideradas por eles como demoníacas. Em parte, é possível concluir que o crescimento do fenómeno do exorcismo 
decorre do alargamento e adesão a práticas culturais, religiosas e desportivas decorrentes da globalização. Também não será despropositado conjeturar que estas mesmas práticas, em que se inclui a capoeira, sejam reforçadas por oposição a esta demonialização e à investida conservadora da Igreja. Para alguns dos praticantes polacos, existe a clara noção da necessidade do combate o conservadorismo e, para este efeito, devem ser reforçadas as práticas consideradas de má presença na sociedade polaca.

Consta que um dos possíveis espíritos que possuíram Palka, o mestre Bimba, segundo Sodré (2002), era filho de Xangô, divindade do Candomblé associada à justiça. Diz-se ainda que era ogã-alabê, um cargo religioso que permite conduzir o ritual tocando um dos três tambores associados ao culto. Sodré relata que, após a morte do mestre no Estado de Goiás, teria sido noticiado nos jornais locais que ele reapareceu enquanto fantasma nas cercanias de sua antiga habitação. Familiares de Bimba relatavam episódios de visões do velho mestre sentado na sua poltrona ou nas esquinas da rua do bairro onde habitava. É curioso que o mestre baiano, bem como outros renomados mestres, tenham escolhido um jovem polaco, num local remoto do velho continente, para fazer a sua reaparição na roda e nos ambientes globais da capoeira. Melhor teria sido que o fizessem na Bahia, nas rodas da cidade de Salvador, onde teriam acolhimento condigno e justas homenagens. Contudo, suspeito que os velhos mestres, conscientes dos tempos globais e da inimaginável difusão da capoeira, tenham desejado pregar aos praticantes uma nova lição, mostrar-lhes que os "espíritos da capoeira", bem como os seus zeladores ancestrais, podem reaparecer em qualquer lugar, tendo sido a Polônia e Palka os seus escolhidos. Pena que o jovem Dominik não tenha tido uma compreensão profunda dos factos sociais e espirituais de que foi alvo. Não tenho a menor dúvida de que Palka tenha sido possuído pelos espíritos dos mestres e, tal como ele, muitos outros nos mais recônditos espaços mundiais onde a capoeira tem chegado.

Entendo a possessão, neste caso, num sentido metafórico, de possuir algo ou possuirse por algo que se entranha em profundidade. Qualquer praticante, depois de algum tempo, sente-se possuído, entranhado com uma cultura que possui um apelo ao passado e a um legado que remonta a tempos pretéritos e mestres fundadores. O que ocorreu com Palka, ao nível individual, foi um estranhamento que gerou uma repulsão e uma possessão indesejada, um dilema advindo da pressão social de valores de setores conservadores da sua sociedade que compreendiam a capoeira como demoníaca e, como tal, perigosa para o bem-estar físico, espiritual e religioso dos cristãos da Polônia.

À parte da compreensão do fenómeno, no plano individual, de Dominik Palka, há um debate curioso a travar sobre a religiosidade e a cultura na Polônia. Recordo a importância e o papel 
do catolicismo na sociedade polaca, a sua relevância no que toca à construção da identidade nacional, o combate aos regimes autoritários, dos quais foi, por ambiguidade, algumas vezes cúmplice mas também beligerante e o seu funcionamento como agente moral no período de retorno da Polônia ao capitalismo e à sua inserção geopolítica no quadro da cultura e da economia global.

\section{Referências bibliográficas}

ACETI, Monica. Devenir et rester capoeiriste en europe: transmissions interculturelles et 'mondialité' de la capoeira afro-brésilienne. Tese de Doutoramento em Sociologia. Université de France Comté, 2011.

BRITO, Celso, 2012, "La mandinga? ...c'est dur, mais ça m'échappe!: exercício antropológico sobreconcepções de franceses e brasileiros acerca da mandinga na Capoeira Angola", Actas del I Encuentro Latinoamericano de Investigadores sobre Cuerpos y Corporalidades en las Culturas, Facultad de Humanidades y Artes, Universidad Nacional de Rosario, Rosario, Argentina.

CALAINHO, Daniela Buono. Metrópole das mandingas: religiosidade negra e inquisição portuguesa no antigo regime. Rio de Janeiro, Garamond, 2008.

CAMPOS, Roberta Bivar; GUSMÃO, Eduardo Henrique. Celebração da fé: rituais de exorcismo, esperança e confiança, na IURD. Revista Antropológicas. Programa de Pósgraduação em Antropologia da Universidade Federal de Pernambuco. V. 19, n. 1, 2008.

DECÂNIO FLHO, Ângelo Augusto. Transe capoeirano: um estudo sobre a estrutura do ser humano e modificações do estado de consciência durante a prática da capoeira. CEPAC. Coleção São Salomão. Nº 5. Salvador, 2002.

FELIZ, Aboyomi, Mandela Silva. Permacultura e Capoeira Angola: Análise de Redes e estruturação de unidades demonstrativas na nova PNATER. Dissertação e mestrado, Universidade de Brasilia, 2014.

FERNANDES, Fábio Araújo. Capoeiragem In Between: um estudo etnográfico sobre a prática da capoeira na Alemanha. Tese de doutoramento em Antropologia. Universidade Federal de Santa Catarina, 2014.

GRANADA, Daniel. Les mestres, les groupes et les «lieux dynamiques » Identité et relocalisation de la pratique de la capoeira à Paris et à Londres. Tese de doutoramento em Antropologia. Université de Paris e University of Essex, 2013.

GUIZARDI, Menara Lube. Todo lo que la boca come. Flujos, rupturas y fricciones de la capoeira en Madrid. Tese de doutoramento em Antropologia. Universidade Autónoma de Madrid, Espanha, 2011. 
GALENT, Marcin; KUBICI, Pawel. "New Urban Middle Class and National Identity in Poland", Polish Sociological review, 3 (179): 386-400, 2012.

LEWIS, Ioan M. Êxtase religioso. São Paulo, Editora Perspectiva, 1997.

LIGIÉRO, Zeca. Corpo a corpo: estudo das performances brasileiras. Rio de Janeiro, Editora Garamond, 2011.

MUNIZ, Sodré. Mestre Bimba, corpo de mandinga. Rio de Janeiro, Manati, 2002.

PALKA, Dominik. “Czy cappoeira tylko sport?”, Revista O Egzorcysta, 7. Cracóvia, Polônia, 2013.

PALKA, Dominik. “Taniec na cześć bałwanów”, Revista O Egzorcysta, 7. Cracóvia, Polônia, 2013.

PEREIRA, Diolino. A capoeira de braços para o ar: Um estudo da capoeira Gospel no ABC paulista. Dissertação de Mestrado em Ciências da Religião. São Paulo, Universidade Metodista de São Paulo, 2007.

PINTO, Paulo Mendes e Rijo, Marisa José. Pocessões Exorcismos e demônios: A atualidade de práticas crenças ancestrais na visão do mundo. Lisboa, Editora Sinais de fogo, 2014.

NASCIMENTO, Ricardo César Carvalho. Mandinga for export: a globalização da capoeira. Tese de Doutorado em Antropologia. Faculdade de Ciências Sociais e Humanas da Universidade Nova de Lisboa. 2015. 